\title{
THE EFFECT OF AUDITOR'S COMPETENCY, PROFESSIONALISM AND EXPERIENCE ON MATERIALITY LEVEL CONSIDERATIONS \\ Muhammad Naufal Hilmi ${ }^{1}$ Novita $^{2}$ \\ 1 Universitas Trilogi Jakarta, Indonesia \\ 2 Universitas Trilogi Jakarta, Indonesia naufalhilmi98@gmail.com
}

\begin{tabular}{l} 
INFO ARTIKEL \\
\hline Histori Artikel : \\
Tgl. Masuk : $11-01-2021$ \\
Tgl. Diterima : 23-02-2021 \\
Tersedia Online : 31-03-2021 \\
\hline Keywords: \\
Competence; Professionalism; \\
Auditor Experience; Materiality \\
Level
\end{tabular}

ABSTRAK/ABSTRACT

This study aims to prove the existence of a positive effect of competence, professionalism and experience of auditors on consideration of materiality levels. The sample of this research is 100 auditors obtained using purposive sampling technique. This research is a quantitative research with primary data through distributing questionnaires. Methods of data analysis in this study using the Partial Least Square (PLS) method. The results of this study prove that the competence, professionalism and experience of auditors have a positive effect on the consideration of the level of materiality of auditors who work in KAP DKI Jakarta Region.

\section{PENDAHULUAN}

Harapan masyarakat tentang implementasi dan pelaporan laporan keuangan yang bersih maka dibutuhkan pemeriksaan oleh auditor yang sesuai dengan standar. Tetapi kasus mengenai akuntan publik yang semakin sering terjadi di Indonesia mulai dari kasus BDO Indonesia saat mengaudit Garuda Indonesia yang mengalami kekeliruan saat memberikan opini audit dan melanggar SA 500 dan SA 560, KAP yang mengaudit Jiwasraya dan Asabri karena memberikan opini tidak sesuai dengan kode etik terhadap laporan keuangan dan kasus 2 KAP yang mengaudit SNP Finance karena melanggar standar audit internasional membuat penulis semakin tertarik untuk meneliti penelitian ini. Karena pada kasuskasus di atas peneliti yakin bahwa kompetensi, profesionalisme dan pengalaman auditor memiliki pengaruh besar bagi auditor dalam menjalankan proses audit.

Laporan keuangan dikatakan materialitas atau tidak saat besarnya nilai yang dihilangkan atau salah saji informasi akuntansi yang dilihat dari keadaan yang melingkupinya dapat mengakibatkan perubahan atas suatu pengaruh terhadap pertimbangan orang yang meletakkan kepercayaan terhadap informasi itu, karena adanya penghilangan atau salah saji itu. Hal itu mengharuskan auditor untuk mempertimbangkan keadaan yang berkaitan dengan entitas dan kebutuhan informasi pihak dalam meletakkan kepercayaan atas laporan keuangan auditan. Auditor melakukan audit atas laporan keuangan suatu perusahaan dengan tujuan untuk membuktikan bahwa laporan keuangan tersebut wajar dan akurat melalui opini audit yang mereka berikan. Karena itu, dalam audit atas laporan keuangan, auditor memberikan keyakinan seperti jumlah-jumlah yang 
disajikan dalam laporan keuangan beserta pengungkapannya telah dicatat, diringkas, digolongkan, dan dikompilasi telah mengumpulkan bukti audit yang cukup sebagai dasar memadai untuk memberikan pendapat atas laporan keuangan auditan. Arens (2012:250) mengatakan materialitas adalah besarnya suatu pengabaian atau salah saji informasi akuntansi yang diluar keadaan di sekitarnya, memungkinkan bahwa pertimbangan seseorang yang bergantung pada informasi tersebut dapat berubah atau terpengaruh oleh pengabaian atau salah saji tersebut. Materialitas disebutkan dalam SA 320 IAPI (2013) bahwa dalam tahap perencanaan audit dan pelaksanaan audit mengharuskan auditor untuk mempertimbangkan materialitas dalam perencanaan audit dan penilaian terhadap kewajaran laporan keuangan secara keseluruhan sesuai dengan prinsip akuntansi di Indonesia.

Menentukan tingkat materialitas dipengaruhi oleh beberapa faktor, salah satunya adalah kompetensi. Kompetensi auditor adalah kemampuan yang dimiliki auditor dalam bentuk pengetahuan dan pengalamannya yang cukup dan eksplisit dapat melakukan audit secara objektif, cermat dan seksama. Dengan memiliki tingkat pengetahuan, kemampuan berkomunikasi dan ketelitian yang tinggi seorang auditor akan menghasilkan audit yang berkualitas baik untuk dapat dipaparkan di hadapan pengguna laporan keuangan. Idawati \& Eveline (2016) menguji pengaruh antara kompetensi auditor terhadap pertimbangan tingkat materialitas yang menghasilkan bahwa pengaruh kompetensi terhadap pertimbangan tingkat materialitas positif signifikan. Dalam SA 210 IAPI (2013) paragraf $A 1$ dijelaskan bahwa audit hanya boleh diterima jika auditor mempertimbangkan bahwa ketentuan etika yang relevan seperti independensi dan kompetensi akan dipenuhi, untuk dapat terpenuhinya kualitas audit yang baik maka auditor harus menjalankan tugasnya dalam memenuhi pemeriksaan harus berpegang pada etika akuntan yang ada dalam standar audit. Untuk menjalankan pemeriksaan yang sesuai dengan etika profesi akuntan maka auditor harus memiliki kompetensi yang memadai dalam menjalankan tugasnya demi menghasilkan kualitas audit yang baik.

Selain harus memiliki kompetensi seorang auditor diharuskan memiliki profesionalisme dalam melakukan proses audit. Profesionalisme juga menjadi syarat utama bagi seseorang yang ingin menjadi seorang auditor eksternal. Auditor yang profesional dalam menjalankan penugasannya harus memiliki keyakinan, independensi, evaluasi kerja dan pengambilan keputusan yang baik ketika memeriksa laporan keuangan milik klien perusahaan mereka dan diharapkan menghasilkan audit yang sesuai dengan standar yang diatur oleh undang-undang dan ketentuan perusahaan. Karena sifat profesionalisme sangat dibutuhkan dalam melakukan pekerjaannya maka dengan mengikuti berbagai macam seminar, pelatihan dan pendidikan lanjutan, auditor dapat dengan mudah memiliki sifat profesionalisme dalam dirinya. Karena dengan mengikuti berbagai pelatihan diatas dapat dipastikan auditor semakin memiliki kemampuan bekerja di bidangnya dengan baik dan profesional. Profesionalisme auditor merupakan salah satu dari kode etik auditor seperti yang diatur dalam SA 200 IAPI (2013) paragraf A15, prinsip-prinsip dasar yang harus dipatuhi oleh auditor menurut kode etik adalah sebagai berikut: integritas, objektivitas, kompetensi dan kecermatan profesional, kerahasiaan, perilaku profesional. Dan dalam SA 200 IAPI (2013) paragraf A24 karakteristik unik pertimbangan profesional yang diharapkan dari seorang auditor adalah pertimbangan yang dibuat oleh seorang auditor yang pelatihan, pengetahuan, dan pengalamannya telah membantu pengembangan yang diperlukan untuk mencapai pertimbangan-pertimbangan wajar yang dibuat. Sofia \& Trisatya (2017) menguji hubungan antara profesionalisme terhadap pertimbangan tingkat materialitas yang menghasilkan hubungan positif.

Auditor eksternal juga harus memiliki pengalaman yang baik dalam melaksanakan proses audit. Mulyadi 
(2012) mengatakan bahwa pengalaman auditor merupakan akumulasi gabungan dari semua yang diperoleh melalui interaksi maka dapat direpresentasikan bahwa pengalaman auditor adalah kondisi dimana auditor mempunyai keahlian di bidang audit yang dengan tekun melakukan pembelajaran dari kejadiankejadian yang pernah auditor temukan di penugasan sebelumnya. Seorang auditor dapat dikatakan memiliki pengalaman yang cukup dengan melihat dari lamanya auditor bekerja, banyaknya penugasan yang dijalankan, dan jumlah dari jenis perusahaan yang pernah diaudit. Karena dengan seperti itu dapat dilihat bahwa auditor memperoleh banyak pengetahuan dari penugasan sebelumnya, tingkat kepercayaan diri dan tingginya tingkat skeptisisme auditor dalam mengaudit. Karena sangat dibutuhkannya sebuah pengalaman dalam diri auditor maka dengan melakukan audit di beberapa jenis perusahaan yang berbeda, maka auditor dapat dengan mudah mendapatkan pengalaman yang berbeda pula sehingga keputusan auditor dalam menentukan tingkat materialitas menjadi lebih efektif. Pengalaman auditor disebutkan dalam SA 210 IAPI (2013) bahwa audit harus dilaksanakan oleh seorang atau lebih yang memiliki keahlian dan pelatihan teknis yang cukup sebagai auditor. Dengan pengetahuan yang dimiliki auditor maka akan menghasilkan kualitas audit yang lebih baik dibandingkan dengan yang tidak mempunyai pengetahuan. Semakin banyak pengalaman yang dimiliki auditor maka semakin banyak dugaan yang dapat ditemukan dalam temuan audit. Dalam penelitian Utami (2017) dijelaskan bahwa pengalaman seorang auditor berpengaruh positif terhadap pertimbangan tingkat materialitas.

Penelitian ini dilakukan untuk lebih meyakinkan bahwa pertimbangan tingkat materialitas yang diberikan oleh seorang auditor sangat ditentukan oleh kompetensi, profesionalisme, serta pengalaman. Perbedaan penelitian ini dengan penelitian Sofia \& Trisatya (2017), Idawati \& Eveline (2016) dan Utami (2017) adalah dalam mengembangkan variabel penitian didasarkan pada standar audit yang dikeluarkan oleh IAPI dengan tujuan untuk lebih memberikan keyakinan pada hasil bahwa seorang auditor dalam memberikan pertimbangan tingkat materialitas dipengaruhi kompetensi, profesionalisme, serta pengalaman. Sehingga tujuan penelitian ini adalah melihat pengaruh kompetensi, profesionalisme dan pengalaman auditor dalam membuat laporan audit dan mempertimbangkan tingkat materialitas agar sesuai dengan standar audit yang sedang berlaku di Indonesia.

\section{KERANGKA TEORITIS DAN PENGEMBANGAN HIPOTESIS}

\section{Stakeholder Theory}

Definisi stakeholder menurut Freeman \& McVea (2001) adalah setiap kelompok atau individu yang dapat mempengaruhi atau dipengaruhi oleh pencapaian tujuan organisasi. Teori stakeholder adalah teori yang menggambarkan kepada pihak mana saja perusahaan bertanggung jawab (Freeman \& McVea, 2001). Perusahaan harus menjaga hubungan dengan stakeholder- nya dengan mengakomodasi keinginan dan kebutuhan stakeholder-nya, terutama stakeholder yang mempunyai power terhadap ketersediaan sumber daya yang digunakan untuk aktivitas operasional perusahaan, misal tenaga kerja, pasar atas produk perusahaan dan lain-lain (Chariri \& Ghozali, 2007). Munculnya teori stakeholders sebagai paradigma dominan semakin menguatkan konsep bahwa perusahaan bertanggung jawab tidak hanya kepada pemegang saham melainkan juga terhadap para pemangku kepentingan atau stakeholder (Maulida \& Adam, 2012).

Dalam mengembangkan stakeholder theory Freeman (1984) dalam Susanto \& Tarigan (2013) memperkenalkan konsep stakeholder dalam dua model yaitu: (1) model kebijakan dan perencanaan bisnis; dan (2) model tanggung jawab sosial perusahaan dari manajemen stakeholder. Pada model pertama, fokusnya adalah 
mengembangkan dan mengevaluasi persetujuan

\section{Materialitas}

Definisi materialitas menurut Arens (2015:275) adalah besarnya nilai yang dihilangkan atau salah saji informasi akuntansi, dilihat dari keadaan yang melingkupinya, yang mungkin dapat melibatkan perubahan pengaruh terhadap pertimbangan orang yang meletakan kepercayaan atas informasi tersebut karena adanya penghilangan atau salah saji tersebut. Standar yang tinggi dalam praktik akuntansi akan memecahkan masalah yang berkaitan dengan konsep materialitas. Pedoman materialitas yang beralasan, yang diyakini oleh sebagian besar anggota profesi akuntan adalah standar yang berkaitan dengan informasi laporan keuangan bagi para pemakai, akuntan harus menentukan berdasarkan pertimbangannya tentang besarnya sesuatu atau informasi yang dikatakan material. Berdasarkan definisi diatas dapat disimpulkan bahwa materialitas adalah besarnya salah saji yang dapat mempengaruhi keputusan pemakai informasi dan pertimbangan seseorang yang meletakan kepercayaan terhadap salah saji tersebut.

Konsep materialitas menyatakan bahwa tidak semua informasi keuangan diperlukan atau tidak semua informasi seharusnya dikomunikasikan. Dalam laporan akuntansi hanya informasi material yang seharusnya disajikan. Informasi yang tidak material sebaiknya dihilangkan. Hal tersebut dapat dianalogikan bahwa konsep materialitas juga tidak memandang secara lengkap terhadap semua kesalahan, hanya kesalahan yang mempunyai pengaruh material yang wajib diperbaiki. Material seharusnya tidak hanya dikaitkan dengan keputusan investor, baik yang hanya berdasarkan tipe informasi tertentu maupun metode informasi yang disajikan.

Penelitian ini menjadi berbeda karena dalam mengembangan variabel penitian didasarkan pada standar audit yang dikeluarkan oleh IAPI untuk lebih memberikan keyakinan pada hasil bahwa seorang auditor dalam memberikan pertimbangan tingkat materialitas dipengaruhi kompetensi, profesionalisme, serta pengalaman. Sehingga tujuan penelitian ini adalah melihat pengaruh kompetensi, profesionalisme dan pengalaman auditor dalam membuat laporan audit dan mempertimbangkan tingkat materialitas agar sesuai dengan standar audit yang sedang berlaku di Indonesia.

\section{Kompetensi Auditor}

Kompetensi didefinisikan sebagai keahlian yang cukup yang secara eksplisit dapat digunakan untuk melakukan pekerjaannya secara objektif (Efendy 2010). Aspek aspek pribadi ini mencakup sikap, motif-motif, sistem nilai, sikap, pengetahuan, pengalaman, dan keterampilan dimana kompetensi akan mengarahkan tingkah laku.

Standar umum audit pasal satu menyebutkan bahwa audit harus dilaksanakan oleh seorang yang lebih memiliki keahlian dan pelatihan teknis yang cukup sebagai auditor. Seberapapun tingginya kemampuan seseorang dalam bidang-bidang lain, termasuk dalam bidang bisnis keuangan, ia tidak dapat memenuhi syarat yang dimasukan dalam standar auditing ini jika ia tidak memiliki pendidikan serta pengalaman memadai dalam bidang auditing.

Arens Arens (2012) menegaskan bahwa: "Auditor harus memiliki kualifikasi untuk memahami kriteria yang digunakan dan kompeten untuk mengetahui jenis serta jumlah bukti yang akan dikumpulkan guna mencapai kesimpulan yang tepat setelah memeriksa bukti itu". Arens (2012) juga menegaskan bahwa kompetensi orangorang yang bertugas untuk melaksanakan kegiatan audit tidak akan ada nilainya apabila tidak bersikap independen dalam mengumpul kan dan mengevaluasi bukti.

Menurut Tuana Kota (2011) kompetensi merupakan keahlian seorang auditor yang diperoleh dari pengetahuan, pengalaman, dan pelatihan. Setiap auditor wajib memenuhi persyaratan tertentu untuk menjadi auditor. Pada awal lahirnya 
profesi ini, persyaratan masih sederhana. Dengan berkembangnya ilmu dan pengetahuan dan semakin kompleksnya dunia usaha, persyaratan menjadi auditor semakin ketat.

\section{Profesionalisme}

Profesi dan profesionalisme dapat dibedakan secara konseptual. "Profesi merupakan jenis pekerjaan yang memenuhi beberapa kriteria, sedangkan profesionalisme merupakan suatu atribut individual yang penting tanpa melihat suatu pekerjaan yang merupakan suatu profesi atau tidak" Fogart dalam (Annisa \& Wahyundaru, 2013). Seorang auditor bisa dikatakan profesional apabila telah memenuhi dan mematuhi standar-standar kode etik yang telah ditetapkan oleh IAI.

Profesionalisme yang digunakan adalah konsep untuk mengukur bagaimana para profesional memandang profesi mereka yang tercermin dalam sikap dan perilaku mereka. Dengan anggapan bahwa sikap dan perilaku mempunyai hubungan timbal balik. Perilaku profesionalisme merupakan cerminan dari sikap profesionalisme, demikian pula sebaliknya sikap profesional tercermin dari perilaku yang profesional. Sikap profesional tercermin pada pelaksanaan kualitas yang merupakan karakteristik atau tanda suatu profesi atau seorang profesional. Dalam pengertian umum, seseorang dikatakan profesional jika memenuhi tiga kriteria, yaitu mempunyai keahlian untuk melaksanakan tugas sesuai dengan bidangnya, melaksanakan suatu tugas atau profesi dengan menetapkan standar baku di bidang profesi yang bersangkutan, dan menjalankan tugas profesinya dengan mematuhi etika profesi yang ditetapkan

\section{Pengalaman Auditor}

Pengalaman audit dapat dilihat dari jenjang seorang auditor menjabat dalam struktur suatu tempat, waktu bekerja, keahlian auditor yang berhubungan dengan audit, serta pelatihan-pelatihan yang pernah diikuti oleh auditor. Pengalaman auditor eksternal dapat diperoleh dari berbagai cara seperti mengikuti pelatihan formal maupun dari pengalaman khusus, kegiatan seminar, lokakarya serta pengarahan dari auditor yang lebih senior darinya. Pemerintah mensyaratkan pengalaman kerja sekurang-kurangnya tiga tahun sebagai akuntan dengan reputasi baik di bidang audit bagi akuntan yang ingin Memperoleh izin praktik dalam profesi akuntan publik (SK Menteri Keuangan No.43/KMK.017/1997 tanggal 27 januari 1997). Pengalaman auditor dapat menentukan profesionalisme kinerja, komitmen terhadap organisasi, serta kualitas auditor melalui pengetahuan yang diperoleh dari pengalaman melakukan audit.

Menurut SPAP (2013) dalam Standar Umum Pertama PSA No.4 menyatakan bahwa seberapapun tinggi keahlian seseorang dalam bidang lain, termasuk dalam bidang bisnis dan keuangan, auditor belum dapat dikatakan memenuhi syarat standar auditing apabila auditor tidak mempunyai pendidikan dan pengalaman yang memadai dalam audit. Pencapaian keahlian tersebut dimulai dengan pendidikan formalnya, tetapi dapat juga diimbangi dengan pengalaman pengalaman selanjutnya dalam praktik audit. Seorang auditor yang baru masuk dalam karir auditing harus memperoleh pengalaman profesionalnya dengan cara mendapatkan supervisi dan di review atas pekerjaannya di lapangan dari atasannya yang lebih berpengalaman

\section{Pengaruh kompetensi auditor terhadap pertimbangan tingkat materialitas}

Semakin banyak kasus keuangan baik domestik maupun mancanegara, sebagian kasus tersebut terjadi mulai dari laporan keuangan yang dipublikasikan oleh perusahaan. Praktik-praktik kecurangan seperti ini yang sudah seharusnya diluruskan oleh auditor agar para pengguna laporan keuangan mendapat informasi yang relevan dan reliable. Hal ini sangat berbanding lurus dengan kompetensi auditor yang harus terus ditingkatkan, tingkat materialitas menjadi suatu hal yang sangat vital bagi seorang auditor untuk memberikan opini pada laporan audit dan dalam penelitian Utami (2017) dapat disimpulkan bahwa 
ada hubungan yang signifikan antara kompetensi dan pertimbangan tingkat materialitas. Dengan pengetahuan, kemampuan berkomunikasi dan ketelitian yang dimiliki auditor diharapkan kompetensi seorang auditor semakin baik sehingga menjadikan auditor semakin baik dalam menentukan besarnya tingkat materialitas laporan keuangan suatu perusahaan yang sedang diperiksanya. Berdasarkan penjelasan tersebut dapat dibangun hipotesa 1 seperti berikut:

$\mathrm{H} 1$ : Kompetensi berpengaruh terhadap pertimbangan tingkat materialitas

\section{Pengaruh profesionalisme terhadap pertimbangan tingkat materialitas}

Alasan diperlukannya perilaku profesional yang tinggi pada setiap profesi adalah kebutuhan akan kepercayaan publik terhadap kualitas jasa yang diberikan. Seorang auditor penting untuk meyakinkan klien dan pemakai laporan keuangan akan kualitas auditnya, kemampuan para auditor itu untuk memberikan jasa kepada klien dan masyarakat secara efektif akan berkurang dan dalam penelitian Idawati dan Eveline (2016) dijelaskan bahwa seorang auditor professional pasti akan bertanggung jawab melaksanakan tugasnya dengan tekun dan seksama mulai dari merencanakan hingga melakukan tugasnya dengan keterampilan dan kepedulian yang secara umum diharapkan dari akuntan profesional. Dengan keyakinan, independensi, evaluasi kerja dan pengambilan keputusan diharapkan auditor memiliki sikap profesional yang tinggi sehingga lebih baik dalam menentukan tingkat materialitas. Dari penjelasan tersebut dapat dibangun hipotesa 2 seperti berikut:

$\mathrm{H} 2$ : Profesionalisme berpengaruh terhadap pertimbangan tingkat materialitas

\section{Pengaruh pengalaman terhadap pertimbangan tingkat materialitas}

Auditor yang berpengalaman dapat melakukan pertimbangan yang baik dalam mengambil keputusan saat mereka menjalankan tugasnya. Pengalaman merupakan salah satu elemen penting dalam melaksanakan tugas audit sehingga cara auditor memandang dan menanggapi informasi yang didapat selama melakukan pemeriksaan akan berbeda, demikian halnya saat auditor mengambil keputusan kemudian terdapat penjelasan dari hasil penelitian Sofia dan Trisatya (2017) mereka menyatakan bahwa pengalaman auditor memiliki pengaruh positif signifikan terhadap pertimbangan tingkat materialitas. Dengan melihat mulai dari lamanya auditor bekerja, banyaknya penugasan yang ditangani sampai banyaknya jenis perusahaan yang pernah diaudit diharapkan seorang auditor dapat menentukan tingkat materialitas suatu laporan keuangan dengan semakin baik. Dari penjelasan tersebut dapat dibangun hipotesa 3 seperti berikut:

H3: Pengalaman auditor berpengaruh terhadap pertimbangan tingkat materialitas

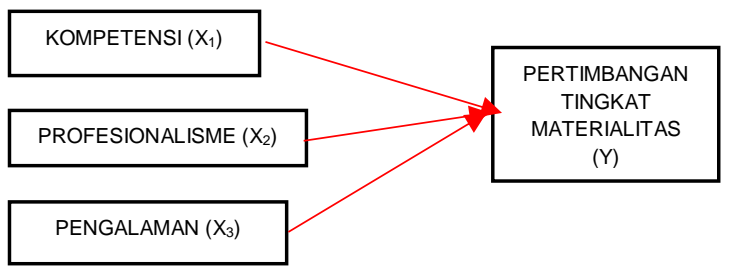

Gambar 1. Model Penelitian

\section{METODOLOGI PENELITIAN}

Penelitian ini menggunakan metode kuantitatif dengan menggunakan data primer, data primer data yang berasal langsung dari sumber data yang dikumpulkan secara khusus dan berhubungan langsung dengan permasalahan yang diteliti.Teknik sampling yang digunakan dalam penelitian ini adalah nonprobability sampling dengan menggunakan teknik purposive sampling. Pengumpulan data dilakukan dengan metode kuesioner. Kuesioner tersebut diajukan kepada auditor pada KAP terpilih di wilayah DKI Jakarta dengan kriteria memiliki sertifikasi profesi, pernah mengikuti PPL, merupakan anggota profesi akuntan dan memiliki pengalaman kerja minimal 1 tahun. Akuon \& Ridwan (2013) mengatakan jika populasi dalam 
penelitian tidak diketahui maka pengambilan sampel pada penelitian dapat menggunakan rumus pengukuran sampel dari populasi tidak terbatas yaitu:

$$
n=\left(\frac{Z_{\alpha / 2} \sigma}{e}\right)^{2}
$$

Rumus 1. Rumus Sampel dari Populasi Tidak Terbatas

Sumber: (Akuon \& Ridwan, 2013)

Keterangan:

$$
\begin{array}{ll}
\mathrm{n} & \text { : Ukuran sampel } \\
\sigma & \text { : Standar deviasi populasi } \\
\mathrm{e} & \text { : tingkat kesalahan } \\
\mathrm{Z} \alpha & \text { : Nilai tabel } \mathrm{Z}=0.05 \\
& \mathrm{n}=(1,96) \cdot(0,25)^{2} \\
0,05 & =96,04
\end{array}
$$

Jadi, jumlah sampel minimum dalam penelitian ini adalah 100 orang auditor yang bekerja di KAP Wilayah DKI Jakarta yang dihasilkan dari perhitungan diatas sebesar 96,4 yang dibulatkan menjadi 100 sampel.

Teknik pengumpulan data menggunakan angket (kuesioner) yang nantinya diisi oleh responden di KAP terpilih. Pengukuran variabel menggunakan instrumen skala rating dengan skala 1 sampai dengan 4 . Responden diminta memberikan nilai dari pertanyaan/pernyataan dari yang setuju sampai dengan yang tidak setuju. Instrumen kuesioner harus diukur validitas dan reliabilitas datanya oleh karena itu penelitian harus menghasilkan data yang valid dan reliabel. Instrumen yang valid berarti alat ukur yang digunakan itu valid. Valid berarti instrumen tersebut dapat digunakan untuk mengukur yang seharusnya diukur. Sedangkan reliabel yaitu apabila telah digunakan berkali-kali untuk mengukur suatu objek yang sama akan menghasilkan data yang serupa. Analisis yang digunakan adalah analisis deskriptif dan analisis verifikatif dengan SmartPLS versi 3.3.2 dengan menggunakan analisis inner model serta outer model untuk melihat hubungan antar variabelnya. Pengujian ini mempunyai kriteria jika nilai t-statistik lebih baik dibandingkan t-Tabel berarti hipotesis didukung atau diterima. Dalam penelitian ini, tingkat keyakinan 95\% dan alpha sebesar $5 \%$ sehingga $t$-Tabel sebesar 1,96 .

Dalam menentukan tingkat materialitas laporan keuangan diperlukan pertimbangan-pertimbangan yang tidak mudah. Banyak faktor yang mempengaruhi kualitas pertimbangan materialitas. Pertama, kompetensi auditor, semakin tinggi tingkat kompetensi auditor tersebut kualitas pertimbangan tingkat materialitasnya pun akan semakin tepat. Kedua, Profesionalisme Auditor, Semakin auditor bersikap professional maka kualitas pertimbangan tingkat materialitasnya pun akan semakin tinggi. Ketiga, pengalaman auditor, semakin banyak pengalaman yang dimiliki auditor maka pengambilan keputusannya pun akan semakin baik dan matang. Ketiga hal tersebut berbanding lurus karena materialitas adalah sesuatu yang sifatnya relatif, tidak ada peraturan absolut yang mengatur tentang besarnya nilai materialitas suatu entitas. Jadi skill akan tingkat materialitas didapat dari penerapan kompetensi, profesionalisme dan pengalaman auditor selama mereka di dunia audit. Dengan demikian, apabila ketiga faktor tersebut dimiliki oleh seorang auditor, maka pertimbangan tingkat materialitas suatu laporan keuangan akan semakin baik. 


\begin{tabular}{|c|c|}
\hline Variabel & Indikator \\
\hline $\begin{array}{l}\text { Kompetensi }\left(\mathrm{X}_{1}\right) \\
\text { (IAPI, 2013) } \\
\text { (Etika Profesi Seksi } \\
\text { 130) }\end{array}$ & $\begin{array}{l}\text { Pengetahuan } \\
\text { Kemampuan } \\
\text { berkomunikasi } \\
\text { Ketelitian }\end{array}$ \\
\hline $\begin{array}{l}\text { Profesionalisme }\left(\mathrm{X}_{2}\right) \\
\text { (IAPI, 2013) } \\
\text { (Etika Profesi Seksi } \\
\text { 150) }\end{array}$ & $\begin{array}{l}\text { Keyakinan } \\
\text { Independensi } \\
\text { Evaluasi kerja } \\
\text { Pengambilan } \\
\text { keputusan }\end{array}$ \\
\hline $\begin{array}{l}\text { Pengalaman Auditor } \\
\left(X_{3}\right) \\
\text { (Ismiyati, 2012) }\end{array}$ & $\begin{array}{l}\text { Lamanya auditor } \\
\text { bekerja } \\
\text { Frekuensi } \\
\text { penugasan yang } \\
\text { ditangani } \\
\text { Frekuensi dan } \\
\text { ragam jenis } \\
\text { perusahaan yang } \\
\text { pernah diaudit }\end{array}$ \\
\hline $\begin{array}{l}\text { Materialitas (Y) } \\
\text { (IAPI, 2013) } \\
\text { (Sofia and Trisatya, } \\
\text { 2017) }\end{array}$ & $\begin{array}{l}\text { Pentingnya } \\
\text { tingkat } \\
\text { materialitas } \\
\text { Pengetahuan } \\
\text { tentang tingkat } \\
\text { materialitas } \\
\text { Risiko audit }\end{array}$ \\
\hline
\end{tabular}

Tabel 1. Operasional Variabel

Sumber: (IAPI, 2013; Ismiyati, 2012; Sofia \& Trisatya, 2017)

\section{Analisis Verifikatif}

Analisis verifikatif merupakan analisis untuk membuktikan dan mencari kebenaran dari hipotesis yang diajukan. Pengujian hipotesis dalam penelitian ini menggunakan metode Partial Least Square (PLS). Analisis verifikatif dalam Metode PLS terdiri dari dua sub model analisis outer model, analisis inner model, dan pengujian hipotesis. Dijabarkan hasil penelitiannya sebagai berikut:

\section{Analisis Outer Model}

Analisis outer model dilakukan untuk menunjukkan hubungan antara indikator-indikator dengan variabelnya (Ghozali dan Latan, 2015). Selanjutnya dijabarkan hasil analisis yang dilakukan pada outer model, terdapat 2 uji yang dilakukan meliputi uji validitas dan uji reliabilitas data sebagai berikut:

\section{HASIL DAN PEMBAHASAN}

\section{Analisis Deskriptif Variabel Kompetensi, Profesionalisme dan Pengalaman Auditor}

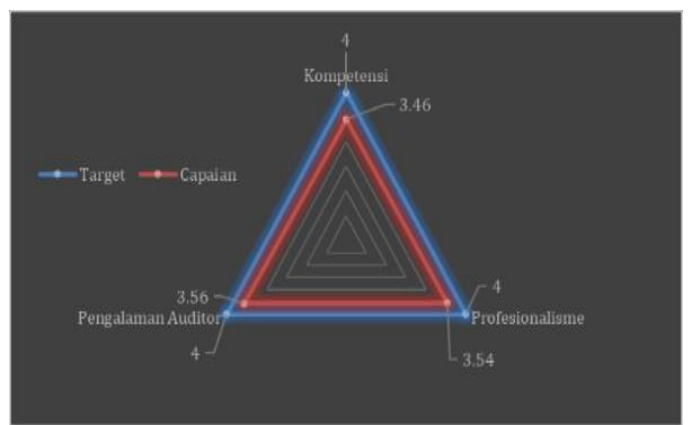

Gambar 2. Analisis Operasional Variabel Dependen

Sumber: Pengolahan Data Primer, 2020

Setelah menyebar kuesioner berdasarkan perhitungan sampel yaitu kepada 100 auditor di wilayah DKI Jakarta pada Gambar 2 menunjukan auditor di wilayah DKI Jakarta menyetujui bahwa kompetensi, profesionalisme dan pengalaman auditor merupakan variabel yang diperlukan oleh seorang auditor dalam menjalankan profesinya. Hal ini dapat dilihat bahwa semua variabel mendapatkan poin di atas 3,00. Kompetensi auditor dapat dilihat melalui pengetahuan yang dimiliki, kemampuan auditor dalam berkomunikasi dan ketelitian saat auditor menjalankan prosedur audit. Kompetensi seseorang dapat dikembangkan melalui pelatihan dan pembelajaran yang diikuti olehnya. Untuk melihat seberapa auditor professional dapat dengan cara melihat keyakinan auditor saat melakukan proses audit, tingkat independensi terhadap klien dan atasan, melihat hasil audit yang dilakukan dan pemberian opini auditor untuk pengambilan keputusan. Kemudian pengalaman Auditor dapat dilihat dari beberapa faktor yaitu lamanya auditor bekerja, frekuensi penugasan yang ditangani dan ragam jenis perusahaan yang pernah diaudit. 


\section{Analisis Kompetensi \\ Deskriptif \\ Variabel}

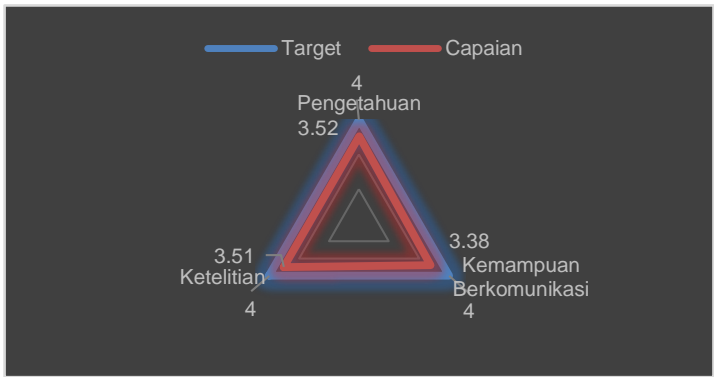

Gambar 3. Hasil Analisis Indikator

Operasional Variabel Kompetensi Sumber: Pengolahan Data Primer, 2020

Gambar 3 menjelaskan bahwa auditor sangat setuju bahwa seorang auditor dituntut untuk selalu memelihara dan meningkatkan pengetahuannya agar dalam memberikan jasa kepada klien dapat memberikan tingkat kepercayaan yang tinggi sehingga sesuai standar profesi dan kode etik profesi yang berlaku. Kemampuan yang dimaksud adalah kemampuan yang harus dimiliki seorang auditor tentang pengembangan Pendidikan profesional berkelanjutan (PPL) untuk bertindak secara kompeten saat melakukan pekerjaannya. Selain itu juga kemampuan auditor dalam mengumpulkan bukti audit saat melakukan proses audit dan mendiskusikan dengan profesional temuan-temuan tersebut dengan rekan setim atau manajer audit. Sehingga dapat disimpulkan bahwa dalam melakukan pekerjaannya, auditor mencakup keseluruhan termasuk tanggung jawab dalam bertindak dan menyelesaikan pekerjaan secara menyeluruh, teliti dan tepat waktu.

\section{Analisis Profesionalisme}

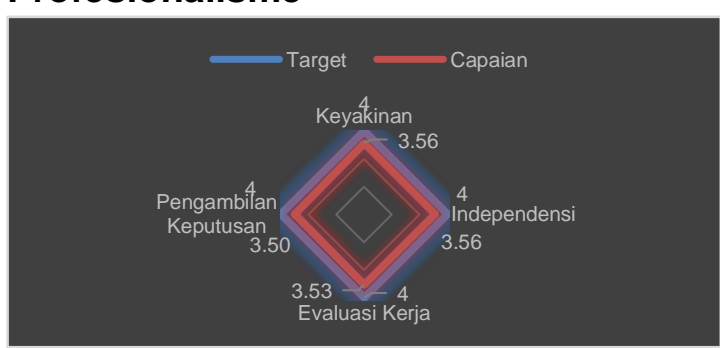

Gambar 4. Hasil Analisis Indikator

Operasional Variabel Profesionalisme Sumber: Pengolahan Data Primer, 2020
Gambar 4 menampilkan hasil bahwa responden sangat setuju bahwa auditor melakukan pekerjaannya dengan perasaan yang bulat bahwa dia melakukan pekerjaan dengan benar dan sesuai standar audit yang berlaku. Dapat dikatakan bahwa auditor melakukan proses audit dalam keadaan tidak terikat atau paksaan dari pihak manapun sehingga auditor melakukan pekerjaan secara mandiri dan independen sehingga menyelesaikan proses audit sesuai dengan standar yang berlaku. Artinya Auditor sangat setuju dan siap menerima bila pekerjaannya dikritisi oleh manajer, rekan sejawat ataupun bagian quality control dengan tujuan yang telah ditetapkan pada proses awal rencana audit. Dapat disimpulkan bahwa proses akhir dari kerja auditor adalah mengambil keputusan, sehingga auditor harus memiliki strategi dalam mengambil keputusan dengan pendiriannya tanpa diganggu gugat oleh orang lain dan berdasarkan standar audit sehingga mampu memberikan opini yang baik dan berkualitas.

\section{Analisis Deskriptif Variabel Pengalaman Auditor}

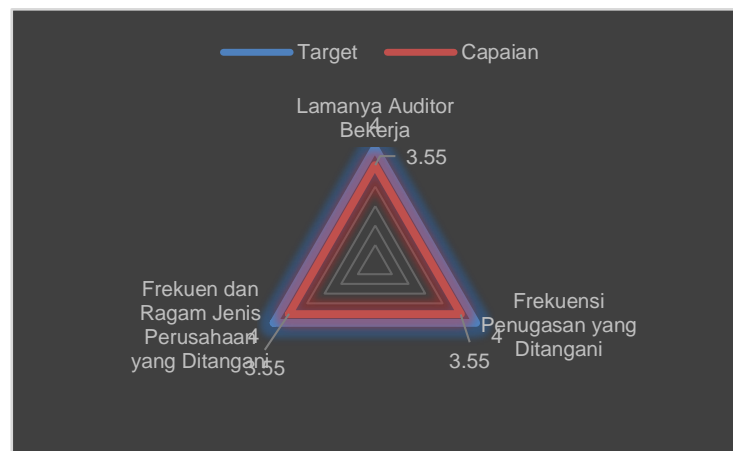

Gambar 5. Hasil Analisis Indikator Operasional Variabel Pengalaman Auditor Sumber: Pengolahan Data Primer, 2020

Dalam Gambar 5 terlihat bahwa tanggapan sangat setuju kembali mendominasi dalam mengukur indikator lamanya auditor bekerja. Artinya pengalaman auditor dapat dilihat dari satuan waktu, kemahiran auditor dalam melakukan pemeriksaan, kemahiran dalam menemukan bukti audit dan menganalisis laporan keuangan. Dengan kata lain pengalaman kerja seseorang 
ditunjukan dengan jenis-jenis pekerjaan ataupun banyaknya penugasan yang pernah dilakukan seseorang dan akan memberikan peluang yang besar untuk melakukan pekerjaan dengan lebih baik, banyaknya penugasan audit yang pernah dilakukan auditor dapat meningkatkan kinerja auditor untuk melakukan penugasan audit dengan lebih baik dan dapat diartikan pengalaman dari banyaknya jenis perusahaan yang pernah diaudit akan memberikan suatu pengalaman yang lebih bervariasi dan bermanfaat untuk meningkatkan pengetahuan dan keahlian auditor. Perbedaan perusahaan akan menentukan langkah atau prosedur audit yang dilakukan menjadi berbeda kecuali untuk bidang usaha yang sama, maka langkahlangkah yang dilakukan auditor akan sama dalam proses audit. Ketika auditor sudah memiliki pengalaman yang cukup memadai dapat dipastikan pengambilan keputusan yang dilakukan lebih dapat diterima dan dijadikan dasar kepercayaan oleh masyarakat dan pengguna laporan keuangan.

\section{Analisis Deskriptif Variabel Pertimbangan Tingkat Materialitas}

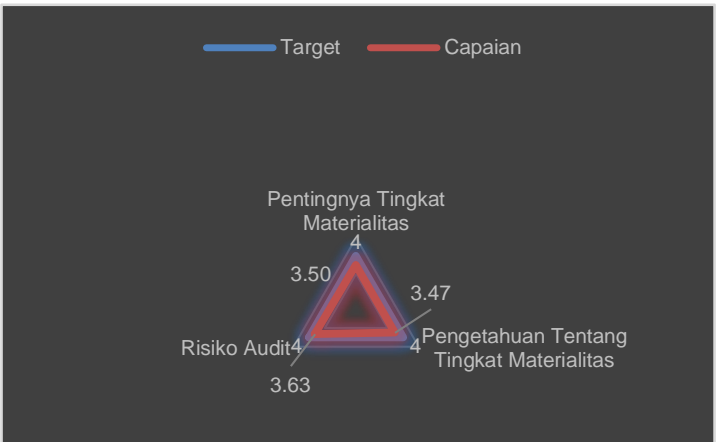

Gambar 6. Hasil Analisis Indikator

Operasional Variabel Pertimbangan Tingkat Materialitas

Sumber: Pengolahan Data Primer, 2020

Dalam Gambar 6 terlihat hasil bahwa indikator pentingnya tingkat materialitas dapat dijadikan pengukur yang baik karena terlihat tanggapan setuju mendominasi yang dapat dinyatakan bahwa materialitas adalah konsep yang vital dalam proses audit karena berhubungan dengan suatu fakta yang akan diungkapkan oleh auditor dengan pertimbangan-pertibangan yang matang agar menghasilkan opini audit yang baik sesuai dengan bukti audit yang ditemukan yang artinya pengetahuan auditor mengenai materialitas harus baik dalam melakukan proses audit selain itu kemampuan mengumpulkan bukti audit pun harus dimiliki pula oleh auditor agar menghasilkan opini yang baik dalam penentuan tingkat materialitas di dalam laporan keuangan yang diperiksa. Salah saji pada pelaporan keuangan menjadi faktor pertimbangan utama dalam menentukan tingkat materialitas karena tingkat materialitas sangat bergantung pada bukti audit yang ditemukan. Ketepatan auditor dalam menentukan tingkat materialitas ditentukan oleh banyak faktor, yaitu kemahiran auditor dalam membuat menganalisis laporan keuangan, menemukan bukti audit dan membuat laporan audit. Semua bukti yang ditemukan oleh auditor harus melalui perhitungan dan pertimbangan risiko audit mulai dari tingkat akun atau golongan transaksi karena risiko audit menentukan sifat, saat dan lingkup prosedur audit. Dalam melakukan audit seorang auditor harus merencanakan prosedur audit dengan baik agar risiko audit dapat dibatasi pada tingkat yang rendah dengan prosedur audit yang baik diharapkan laporan audit yang dihasilkan sesuai dengan standar yang berlaku dan buktibukti yang memadai untuk mewakili hasil audit.

\section{Uji Validitas}

Jawaban yang didapatkan dari responden terhadap semua pernyataan mengenai kompetensi, profesionalisme dan pengalaman auditor terhadap pertimbangan tingkat materialitas pada Kantor Akuntan Publik di wilayah DKI Jakarta merupakan bagian dari faktor yang mempengaruhi tingkat validitas pada penelitian ini. Terdapat beberapa indikator dalam pengujian ini sebagai berikut: 


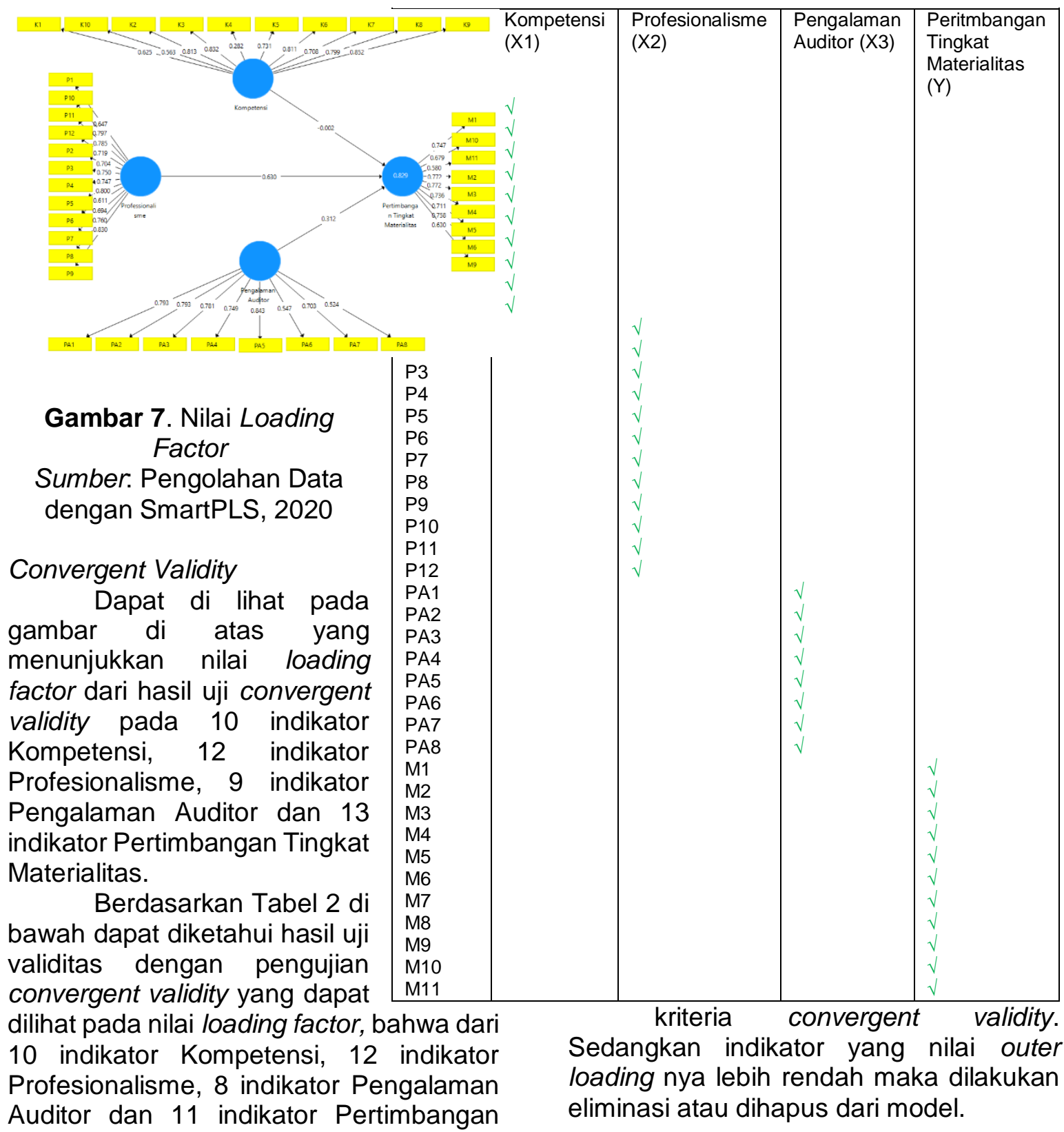

Tingkat Materialitas yang memiliki nilai loading factor dengan nilai korelasi diatas 0.70 . Namun terdapat nilai loading di atas 0.05 sampai 0.60 masih dapat diterima. Nilai outer loading awalnya belum memenuhi convergent validity karena masih terdapat beberapa indikator yang nilai outer loading nya masih dibawah 0.70. Namun, dapat dilihat bahwa mayoritas indikator dari masing-masing variabel memiliki nilai outer loading lebih besar dari 0.70 . Selain dari PA9, M12 dan M13 menunjukkan bahwa indikator variabel memiliki nilai outer loading lebih besar dari 0.70 artinya, memiliki tingkat validitas yang tinggi sehingga dapat memenuhi

Tabel 2. Hasil Analisis Outer Loading Sumber: Pengolahan Data dengan SmartPLS, 2020

Berdasarkan Tabel 2 indikator telah dimodifikasi memiliki nilai outer loading diatas 0.70. Dari total 44 indikator terdapat 3 indikator yang dieliminasi. Sehingga yang tersisa dari semua indikator tersebut menunjukkan validitas yang sangat baik (Ghozali \& Latan, 2015a).

\section{Discriminant Validity}

Berikut ini dapat dilihat hasil uji dari discriminant validity pada gambar di bawah ini: 


\begin{tabular}{|l|c|c|c|c|}
\hline X1 (Kompetensi) & X1 & X2 & X3 & Y \\
X2 & 0.700 & 0.784 & & \\
$\begin{array}{l}\text { (Profesionalisme) } \\
\text { X3 (Pengalaman }\end{array}$ & 0.586 & 0.788 & 0.820 & \\
$\begin{array}{l}\text { Auditor) } \\
\text { Y (Pertimbangan }\end{array}$ & 0.668 & 0.865 & 0.805 & 0.779 \\
$\begin{array}{l}\text { Tingkat } \\
\text { Materialitas) }\end{array}$ & & & & \\
\hline
\end{tabular}

Tabel 3. Hasil Analisis Cross Loading Sumber: Pengolahan Data dengan SmartPLS, 2020

Dari Tabel 3 menunjukkan hasil analisis bahwa uji discriminant validity antara Kompetensi, Profesionalisme dan Pengalaman Auditor Terhadap Pertimbangan Tingkat Materialitas yang dihasilkan dinyatakan valid. Karena dari gambar di atas terlihat bahwa nilai dari hasil uji discriminant validity $0.803,0.784$, 0.820 dan 0.779 , artinya menghasilkan nilai $>0.70$ pada semua variabel yang digunakan.

\section{Average Variance Extracted (AVE)}

Ada pula langkah lain yang dapat digunakan untuk uji validitas dengan melihat dari nilai Average Variance Extracted (AVE) yang dapat dilihat dari Gambar 4.3. Apabila nilai AVE yang dihasilkan di atas 0.50 artinya convergent validity tidak ada masalah dengan variabel yang diuji (Ghozali \& Latan, 2015).

\begin{tabular}{|l|l|}
\hline & Average Variance \\
X1 (Kompetensi) & 0.674 \\
X2 (Profesionalisme) & 0.613 \\
X3 (Pengalaman Auditor) & 0.672 \\
Y (Pertimbangan Tingkat & 0.659 \\
Materialitas) & \\
\hline
\end{tabular}

Tabel 4. Nilai Average Variance Extracted Sumber: Pengolahan Data dengan SmartPLS, 2020

Kompetensi dengan nilai yang dihasilkan sebesar 0.674 , Profesionalisme dengan nilai yang dihasilkan sebesar 0.613, Pengalaman Auditor dengan nilai yang dihasilkan sebesar 0.672 dan Pertimbangan Tingkat Materialitas dengan nilai yang dihasilkan sebesar 0.659 . Secara keseluruhan dapat diartikan bahwa semua variabel telah memiliki nilai lebih dari 0.5 sesuai yang disyaratkan Ghozali \&
Latan (2015) sehingga dapat disimpulkan bahwa tidak ada permasalahan pada model yang di uji.

\section{Uji Reliabilitas}

1. Nilai Cronbach's Alpha

\begin{tabular}{|l|c|}
\hline & $\begin{array}{c}\text { Cronbach's } \\
\text { Alpha }\end{array}$ \\
X1 (Kompetensi) & 0.878 \\
X2 (Profesionalisme) & 0.910 \\
X3 (Pengalaman Auditor) & 0.878 \\
Y (Pertimbangan Tingkat & 0.820 \\
Materialitas) & \\
\hline
\end{tabular}

Tabel 5. Nilai Cronbach's Alpha Sumber: Pengolahan dengan SmartPLS, 2020

Uji reliabilitas menghasilkan nilai cronbach's alpha diatas 0.70 atas semua konstruk yaitu Kompetensi dengan nilai 0.878, Profesionalisme 0.910, Pengalaman Auditor 0.878 dan Pertimbangan Tingkat Materialitas 0.820 . Dapat diartikan jika hasil yang dihasilkan dari penelitian ini dapat dipercaya karena memiliki tingkat reliabilitas tinggi (Ghozali \& Latan, 2015).

\section{Nilai Composite Reliability}

\begin{tabular}{|l|l|}
\hline & Composite Reliability \\
X1 (Kompetensi) & 0.911 \\
X2 (Profesionalisme) & 0.926 \\
X3 (Pengalaman Auditor) & 0.911 \\
Y (Pertimbangan Tingkat & 0.881 \\
Materialitas) & \\
\hline
\end{tabular}

Tabel 6. Nilai Composite Reliability Sumber: Pengolahan dengan SmartPLS, 2020

Nilai dari composite reliability berguna untuk mengukur indikator pada semua konstruk dalam penelitian ini agar dapat diketahui apakah indikator yang digunakan reliabel atau tidak. Maka dihasilkan nilai di atas 0.70. Dapat diartikan bahwa semua konstruk yang digunakan memiliki reliabilitas yang tinggi dan tidak ditemukan permasalahan reliabilitas pada model yang dibentuk sehingga dapat dikatakan baik. Karena hasilnya sebesar 0.911 pada Kompetensi, sebesar 0.926 pada Profesional, sebesar 0.911 pada Pengalaman Auditor dan 
sebesar 0.881 Pertimbangan Tingkat Materialitas.

\section{Analisis Inner Model}

Analisis Inner model dilakukan untuk menilai hubungan antara variabel laten dengan variabel endogen berdasarkan pada substantive theory. Ada beberapa pengujian dalam model struktural ini antara lain:

\section{Path Coefficients}

\begin{tabular}{|l|l|l|l|l|}
\hline X1 (Kompetensi) & X1 & X2 & X3 & Y \\
X2 (Profesionalisme) & & & & 0.158 \\
X3 (Pengalaman & & & & 0.520 \\
Auditor) & & & & 0.268 \\
Y (Pertimbangan & & & & \\
Tingkat Materialitas) & & & & \\
\hline
\end{tabular}

Tabel 7. Hasil Analisis Path Coefficients Sumber: Pengolahan dengan SmartPLS, 2020

Dapat dilihat pada Gambar 4.20 yang menunjukan bahwa konstruk Kompetensi memiliki nilai positif sebesar 0.158 terhadap pertimbangan tingkat materialitas, Profesionalisme memiliki nilai positif sebesar 0.520 terhadap Pertimbangan Tingkat Materialitas, Pengalaman Auditor memiliki nilai positif sebesar 0.268 terhadap Pertimbangan Tingkat Materialitas. Sehingga dapat disimpulkan bahwa konstruk laten memiliki pengaruh positif terhadap konstruk endogen.

\section{R-Square}

Y (Pertimbangan Tingkat Materialitas)

Tabel 8. Hasil Analisis R-Square Sumber: Pengolahan dengan SmartPLS, 2020

Nilai $R$ Square merupakan koefisien determinasi pada variabel endogen. Dapat dilihat pada tabel 8 yang menunjukan nilai $R$ Square (R2) untuk variabel endogen (variabel Pertimbangan Tingkat Materialitas) sebesar 0.829 . Hal ini menunjukan bahwa pengaruh variabel Kompetensi, Profesionalisme dan
Pengalaman Auditor terhadap Pertimbangan Tingkat Materialitas adalah sebesar $82.9 \%$ dan sisanya $18.1 \%$ dipengaruhi oleh variabel lainnya di luar model penelitian ini misalnya independensi dan etika profesi. Pada nilai 0.829 juga dapat menunjukan hubungan yang kuat dan valid karena memiliki nilai $R$ Square lebih dari 0.67 .

2.Predictive Relevance (Q-Square)

\begin{tabular}{|l|l|l|l|}
\hline & SSO & SSE & $\begin{array}{l}Q^{2} \\
(=1 \text { SSE/SS } \\
\text { SO })\end{array}$ \\
X1 (Kompetensi) & $\begin{array}{l}600.00 \\
0\end{array}$ & $\begin{array}{l}600.00 \\
0\end{array}$ \\
X2 & 800.00 & 800.00 & \\
(Profesionalisme & 0 & 0 & \\
) & & & \\
X3 (Pengalaman & 500.00 & 500.00 & \\
Auditor) & 0 & 0 & \\
Y (Pertimbangan & 600.00 & 321.21 & 0.461 \\
Tingkat & 0 & 1 & \\
Materialitas) & & & \\
\hline
\end{tabular}

Tabel 9. Hasil Analisa Q-Square Sumber: Pengolahan dengan SmartPLS, 2020

Berdasarkan tabel 9 menunjukan hasil Q2 sebesar 0.461. Sehingga dapat disimpulkan bahwa variabel Kompetensi, Profesionalisme dan Pengalaman Auditor memiliki nilai relevansi prediktif yang besar terhadap variabel Pertimbangan Tingkat Materialitas.

\section{Uji Hipotesis}

\begin{tabular}{|c|c|c|c|c|c|}
\hline & $\begin{array}{l}\text { Original } \\
\text { Sample } \\
\text { (O) }\end{array}$ & $\begin{array}{l}\text { Sample } \\
\text { Mean } \\
\text { (M) }\end{array}$ & $\begin{array}{l}\text { Stand } \\
\text { ard } \\
\text { Deviati } \\
\text { on } \\
\text { (STDE } \\
\text { V) }\end{array}$ & $\begin{array}{l}T \\
\text { Statis } \\
\text { tics } \\
( \\
\text { |O/ST } \\
\text { DEV| } \\
\text { ) }\end{array}$ & $\begin{array}{l}\mathrm{P} \\
\text { Values }\end{array}$ \\
\hline $\begin{array}{l}\mathrm{XI} \text { (Kompetensi) -> } \\
\mathrm{Y} \quad \text { (Pertimbangan } \\
\text { Tingkat Materialitas) }\end{array}$ & 0.158 & 0.153 & 0.077 & 2.065 & 0.039 \\
\hline $\begin{array}{l}\text { X2 (Profesionalisme } \\
-> \\
\text { Y (Pertimbangan } \\
\text { Tingkat Materialitas) }\end{array}$ & 0.520 & 0.525 & 0.115 & 4.517 & 0.000 \\
\hline $\begin{array}{l}\text { X3 (Pengalaman } \\
\text { Auditor } \rightarrow \quad Y \\
\text { (Pertimbangan } \\
\text { Tingkat Materialitas) }\end{array}$ & 0.268 & 0.271 & 0.118 & 2.265 & 0.024 \\
\hline
\end{tabular}

Tabel 10. Hasil Analisis T-Statistics

Sumber: Pengolahan dengan SmartPLS, 2020

Pada tabel 10 dapat diketahui bahwa nilai t-statistik adalah sebesar 2.065, 4.517 dan 2.265 artinya hipotesis 
diterima atau Kompetensi, Profesionalisme dan Pengalaman Auditor berpengaruh terhadap Pertimbangan Tingkat Materialitas. Kemudian, 2 variabel eksogen berpengaruh signifikan terhadap variabel endogen dan 1 variabel eksogen berpengaruh tidak signifikan terhadap variabel endogen.

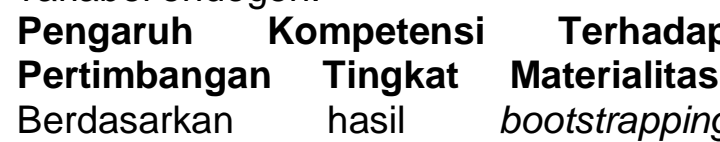
calculation menunjukan nilai original sample sebesar 0.158. Angka tersebut menunjukan bahwa terdapat pengaruh positif dari Kompetensi terhadap Pertimbangan Tingkat Materialitas. Semakin tinggi tingkat Kompetensi, maka semakin baik pula auditor memberikan opini untuk Pertimbangan Tingkat Materialitas. Hal ini dapat dilihat $82.9 \%$ dari Pertimbangan Tingkat Materialitas salah satu faktornya dipengaruhi oleh Kompetensi. Pada Tabel 10 menunjukan bahwa terdapat pengaruh kompetensi dengan pertimbangan tingkat materialitas terlihat pada kolom t-statistic menunjukan angka 2.065 dimana nilai tersebut lebih besar jika dibandingkan dengan kriteria tTabel yaitu 1.96 dengan nilai $p$ value sebesar 0.039 lebih kecil dari kriteria $p$ value yang seharusnya yaitu 0.05 . Maka dapat disimpulkan hipotesis diterima dimana kompetensi berpengaruh terhadap pertimbangan tingkat materialitas. Hasil ini sesuai dengan penelitan Idawati \& Eveline (2016), menyatakan bahwa kompetensi berpengaruh terhadap pertimbangan tingkat materialitas. Responden memberikan pendapat bahwa semakin berkompeten seorang auditor maka semakin baik dalam menentukan tingkat materialitas. Kompetensi merupakan kemampuan auditor dalam menjalankan prosedur sesuai dengan standar. Idawati dan Eveline (2016) beranggapan apabila kemampuan auditor dalam menganalisis laporan keuangan baik maka auditor dapat dengan mudah menentukan tingkat materialitas pada laporan keuangan tersebut. Pengetahuan auditor tentang tingkat materialitas pun menjadi salah satu faktor auditor tersebut dikatakan berkompeten. Ketika auditor mampu menganalisis laporan keuangan dan berhasil mengumpulkan bukti audit yang sesuai dengan perhitungan risiko audit, auditor harus segera melakukan komunikasi dengan rekan setim untuk dapat melaporkan temuan tersebut kepada manajer auditnya. Dalam memeriksa laporan keuangan auditor dituntut untuk memeriksanya secara teliti mulai dari pemeriksaan terhadap golongan transaksi, saldo akun serta penyajian dan pengungkapan laporan tersebut berdasarkan asersi yang telah ditentukan.

Pengaruh Profesionalisme Terhadap Pertimbangan Tingkat Materialitas, Berdasarkan hasil bootstrapping calculation menunjukan nilai original sample sebesar 0.520. Angka tersebut menunjukan bahwa terdapat pengaruh positif dari Profesionalisme terhadap Pertimbangan Tingkat Materialitas. Semakin tinggi Profesionalisme, maka semakin baik pula auditor memberikan opini untuk Pertimbangan Tingkat Materialitas. Hal ini dapat dilihat $82.9 \%$ dari Pertimbangan Tingkat Materialitas salah satu faktornya dipengaruhi oleh Profesionalisme. Pada Tabel 10 di atas menunjukan bahwa pengaruh profesionalisme dengan pertimbangan tingkat materialitas dengan nilai t-statistic sebesar 4.517 lebih besar jika dibandingkan dengan kriteria t-tabel yaitu 1.96 dengan nilai $p$ value sebesar 0.000 lebih kecil dari kriteria $p$-value yang seharusnya 0.05 . Dari hasil tersebut dapat dikatakan hipotesis profesionalisme berpengaruh terhadap pertimbangan tingkat materialitas diterima. Hasil ini sesuai dengan Sofia \& Trisatya (2017) yang menyebutkan bahwa profesionalisme berpengaruh positif signifikan terhadap pertimbangan tingkat materialitas, dalam penelitiannya mereka mengatakan apabila seorang auditor melakukan pekerjaan dengan sikap profesionalisme maka dalam menentukan tingkat materialitas dapat dipastikan auditor mengambil keputusannya pun secara profesional. Seorang auditor dikatakan memiliki sikap profesionalisme apabila auditor memiliki keyakinan yang memadai terhadap temuan-temuan auditnya dengan melakukan pemeriksaan yang sesuai dengan standar audit yang 
berlaku dengan tetap berpegang pada pedoman etika profesi untuk menjadi dasar dalam membuat laporan audit. Sikap profesionalisme juga dapat dilihat dari seberapa independen nya seorang auditor dalam melakukan pemeriksaan yang artinya auditor melakukan pemeriksaan tanpa mendapat tekanan dari pihak manapun dan juga terbebas dari konflik kepentingan terhadap kliennya. Ketika melakukan pemeriksaan auditor juga harus melakukan pemeriksaannya tanpa mendapat pengaruh tentang dan dari pihak manapun. Auditor juga harus terbuka dan menerima apabila hasil pemeriksaannya dikritisi oleh manajer sehingga harus siap melakukan review terhadap laporan audit yang dibuatnya agar menjadi laporan yang baik dan dapat dijadikan dasar kepercayaan bagi masyarakat. Ketika mengambil keputusan auditor yang memiliki sikap profesionalisme pasti memiliki keyakinan yang memadai saat membuat laporan audit dengan mengemukakan bukti audit yang ditemukan selama pemeriksaan agar menghasilkan opini audit sesuai standar yang berlaku.

\section{Pengaruh Pengalaman Auditor Terhadap Pertimbangan Tingkat Materialitas, Berdasarkan hasil} bootstrapping calculation menunjukan nilai original sample sebesar 0.268. Angka tersebut menunjukan bahwa terdapat pengaruh positif dari Pengalaman Auditor terhadap Pertimbangan Tingkat Materialitas. Semakin banyak Pengalaman Auditor, maka semakin baik pula auditor memberikan opini untuk Pertimbangan Tingkat Materialitas. Hal ini dapat dilihat $82.9 \%$ dari Pertimbangan Tingkat Materialitas salah satu faktornya dipengaruhi oleh pengalaman auditor. Pada Tabel 10 menunjukan bahwa pengalaman auditor berpengaruh terhadap pertimbangan tingkat materialitas dengan merujuk pada nilai tstatistic sebesar 2.265 dimana nilai ini lebih besar jika dibandingkan dengan kriteria t-tabel yaitu 1.96 serta nilai $p$ value sebesar 0.025 lebih rendah dari kriteria $p$ value yang seharusnya yaitu 0.05 . Maka dapat disimpulkan bahwa hipotesis pengalaman auditor berpengaruh terhadap pertimbangan tingkat materialitas dapat diterima. Hasil tersebut sesuai dengan penelitian Utami (2017) yang menjelaskan bahwa pengalaman auditor berpengaruh terhadap pertimbangan tingkat materialitas. Dalam penelitian tersebut dikatakan apabila auditor yang berpengalaman lebih mahir dan cepat dalam menentukan tingkat materialitas. Seorang auditor dikatakan berpengalaman apabila auditor tersebut memiliki kemampuan yang memadai dalam melakukan pemeriksaan dan menganalisis laporan keuangan yang dapat mempengaruhinya saat pengambilan keputusan. Penugasanpenugasan yang telah dilakukan pun turut andil dalam menambah pengalaman auditor sehingga dapat membuat auditor mencegah kesalahan pemeriksaan dan semakin memahami prosedur audit yang sesuai dengan standar audit yang berlaku di Indonesia. Setelah menjalani frekuensi pengauditan yang banyak seorang auditor menjadi lebih berpengalaman lagi ketika ragam perusahaan yang diauditnya semakin bervariasi karena tingkat materialitas di setiap perusahaan berbeda dan pasti akan lebih meningkatkan judgment auditor ketika menyelesaikan laporan audit.

\section{KESIMPULAN}

Kompetensi berpengaruh positif signifikan terhadap Pertimbangan Tingkat Materialitas. Kompetensi yang terdiri dari indikator pengetahuan, kemampuan berkomunikasi dan ketelitian dengan tujuan meningkatkan kompetensi auditor dalam menjalankan prosedur audit yang sesuai standar ditunjang dengan pengetahuan yang memadai tentang tingkat materialitas serta selalu mengkomunikasikan temuan audit kepada rekan dan manajer audit diharapkan auditor dapat melakukan pemeriksaan terhadap golongan transaksi, saldo akun serta penyajian dan pengungkapan laporan keuangan berdasarkan asersi dalam laporan keuangan dengan tingkat ketelitian yang tinggi. Profesionalisme 
menjadikan keyakinan, independensi, evaluasi kerja dan pengambilan keputusan sebagai upaya agar auditor dapat melakukan proses audit sampai membuat laporan audit secara profesional. Pengalaman Auditor berpengaruh positif signifikan terhadap Pertimbangan Tingkat Materialitas. Pengalaman Auditor yang diukur dengan indikator lamanya auditor bekerja, frekuensi penugasan yang ditangani dan ragam perusahaan yang diaudit sebagai upaya agar lebih mahir dalam menganalisis laporan keuangan sehingga ketika membuat laporan auditnya dapat mencegah auditor melakukan kesalahan.

\section{IMPLIKASI DAN KETERBATASAN}

\section{Implikasi}

Hasil penelitian ini menunjukkan bahwa kompetensi, profesionalisme dan pengalaman auditor berpengaruh terhadap pertimbangan tingkat materialitas. Dari hasil tersebut memiliki implikasi agar kedepannya KAP khususnya di wilayah DKI Jakarta lebih memperhatikan dan memperbaiki kompetensi, meningkatkan sikap profesionalisme dan memberikan pengalaman audit yang beragam kepada auditornya agar dapat meningkatkan pertimbangan yang baik terhadap tingkat materialitas agar sesuai dengan standarstandar audit yang berlaku.

\section{Keterbatasan}

Faktor-faktor yang mempengaruhi pertimbangan tingkat materialitas dalam penelitian ini hanya terdiri dari tiga variabel yaitu kompetensi, profesionalisme dan pengalaman auditor. Sedangkan masih banyak faktor lain yang mempengaruhi contohnya independensi dan etika profesi. Selain itu penelitian menggunakan kuesioner terkadang responden memberikan jawaban tidak sesuai dengan keadaan sesungguhnya.

\section{REFERENCES}

Akuon, \& Ridwan. (2013). Rumus dan Data dalam Aplikasi Statistika. Alfabeta.

Annisa, V., \& Wahyundaru, S. (2013). Pengaruh Faktor-Faktor Profesionalisme Auditor Dan Etika Profesi Terhadap Tingkat Materialitas Dalam Pemeriksaan Laporan Keuangan. Jurnal Akuntansi Indonesia, 3 No. 2, 113-129.

Arens. (n.d.). Auditing, Assurance Services and Ethics in Australia: An Integrated Approach - Alvin A Arens, Peter John Best, Gregory E. P. Shailer, Mark S. Beasley, Brenton Fiedler, Randal J. Elder - Google Books.

Arens, A., Elder, R., \& Beasley, M. (2015). Auditing \& Assurance Service. Pendekatan Terintegrasi. Erlangga.

Chariri, \& Ghozali. (2007). Teori Akuntansi. Andi.

Efendy. (2010). Pengaruh Kompetensi, Independensi, Dan Motivasi. Tesis S2.

Freeman. (1984). Stakeholder Theory.

Freeman, R. ., \& McVea, J. (2001). "A Stakeholder Approach to Strategic Management". SSRN.

Ghozali, I., \& Latan, H. (2015a). Partial Least Squares Konsep, Teknik dan Aplikasi Menggunakan Program SmartPLS 3.0. Badan Penerbitu Undip.

IAPI. (2013). Standar Audit.

Idawati, W., \& Eveline, R. (2016). Pengaruh Independensi,

Kompetensi, Dan Profesionalisme Auditor Terhadap Pertimbangan Tingkat Materialitas Dalam Pemeriksaan Laporan Keuangan. 
Jurnal Akuntansi/Volume Xx, No. 01, Januari 2016: 16-32, Xx.

Ismiyati. (2012). Pengaruh Pengetahuan dan Pengalaman Auditor terhadap Kualitas Audit (studi empiris pada Kantor Akuntan Publik di Jakarta dan Bekasi. Jurnal Kajian Pendidikan Dan Akuntansi Indonesia, 1 No. 1.

Maulida, \& Adam. (2012). Pengaruh Stakeholder Theory.

Mulyadi. (2012). Sistem Akuntansi Edisi ke-3.

Sofia, I. P., \& Trisatya, D. R. (2017). Pengaruh Pengalaman, Profesionalisme, dan Etika Profesi Auditor Terhadap Penentuan Tingkat Materialitas. Widyakala, 4, 77-79.

Susanto, \& Tarigan. (2013). Penjelasan Stakeholder.

TuanaKotta. (2011). Akuntansi Forensik dan Audit Investigatif. Salemba Empat.

Utami, S. (2017). Pengaruh Independensi, Kompetensi, Pengetahuan Dalam Mendeteksi Kekeliruan Dan Pengalaman Auditor Terhadap Pertimbangan Tingkat Materialitas. Jom Fekon, 4. 